\title{
The Vertical Urban Factory Concept and Sustainable Transport - Prototypes for European Cities
}

\author{
Harald Frey ${ }^{\mathrm{a}}$ Barbara Laa ${ }^{\mathrm{a}^{*}}$, Edeltraud Haselsteiner ${ }^{\mathrm{b}}$, Verena Madner ${ }^{\mathrm{c}}$, Lisa-Maria Grob ${ }^{\mathrm{c}}$, \\ Katja Schwaigerlehner
}

a TU Wien, Research Center of Transport Planning and Traffic Engineering, Vienna, Austria

b Urbanity - Architektur, Kunst, Kultur und Sprache, Wien, Austria

${ }^{c}$ WU Vienna, Research Institute for Urban Management and Governance, Vienna, Austria

\begin{tabular}{|c|c|}
\hline ARTICLE INFO & A B S T R A C T \\
\hline $\begin{array}{l}\text { DOI: } 10.31075 / \text { PIS.66.01.01 } \\
\text { Professional paper } \\
\text { Received: } 23.12 .2019 . \\
\text { Accepted: } 10.01 .2020 . \\
\text { Corresponding author: } \\
\text { barbara.laa@tuwien.ac.at } \\
\text { Keywords: } \\
\text { Urban freight logistics } \\
\text { Urban transport } \\
\text { Sustainable transport } \\
\text { Productive city } \\
\text { Smart city }\end{array}$ & $\begin{array}{l}\text { The Vertical Urban Factory concept reclaims production in multi-story buildings } \\
\text { as part of the cityscape. Today, factories are mostly located in monofunctional } \\
\text { industrial areas outside of cities due to high land prices and restrictions on } \\
\text { motorized individual transport. However, production must be taken into account } \\
\text { as a necessary element of lively and mixed urban structures. New urban } \\
\text { development concepts are therefore in demand for efficient and space-saving use } \\
\text { of commercial and industrial space. We analyzed how multi-story production can } \\
\text { be reintegrated into European cities and developed five prototypes considering } \\
\text { urban structure and logistics concepts. The prototypes show that multi-story } \\
\text { construction is indeed a realizable alternative for limited space resources. While } \\
\text { integrating individual production facilities in densely built-up areas fulfils the } \\
\text { current transport policy objectives best, the greatest potential of vertical } \\
\text { production is located in mixed commercial areas. The vertical urban factory } \\
\text { concept promotes sustainability goals on many levels and we therefore } \\
\text { recommend it to cities. In this paper, we focus on the transportation aspects and } \\
\text { present three of the five prototypes. }\end{array}$ \\
\hline
\end{tabular}

\section{INTRODUCTION}

Production plants in backyards and multi-storey buildings integrated into the street front have been part of the cityscape since industrialisation. Today, they are mostly relocated to monofunctional industrial areas. Mass motorization and the availability of cheap raw materials have massively changed the form of economy and production. The catchment area of raw materials for further use and processing could be expanded as well as the area for possible sales markets. Economies of scale enabled economic and production-specific concentration processes to take place while at the same time providing an extensive sales market (Knoflacher, 1995).

The mixture of residential and working areas contributes significantly to energy-efficient urban development and the achievement of ambitious smart city goals. The potential contribution of urban factories to the sustainable development goals has been analysed in (Juraschek et al., 2018).
However, urban commercial properties are scarce in many places and are not affordable for manufacturing companies with correspondingly large space requirements. In addition, there is pressure to develop new locations for residential construction due to increased urbanisation. In Vienna, for example, since 2001 the space for manufacturing companies has declined by $16.5 \%$, in pure industrial areas the decline is even $30 \%$ (MA 18, 2017).

The decline in the number of business premises, and thus in many cases of urban workplaces, requires measures to be taken to prevent the spatial segregation of living and working areas. The consequences of this spatial decoupling are not only opposing energy spatial planning objectives, also synergy potentials cannot be used sustainably (such as the use of energy/waste heat, closedloop and cascade management, urban value creation, microeconomic local networks). New urban development concepts are therefore in demand for efficient and spacesaving use of commercial and industrial space. 
Alternative concepts to make production in the city attractive again for companies are currently still the exception. While the digital transformation of industrial production is preparing the return of urban industry to mixed-use neighbourhoods (cf. Rappaport, 2016), there are considerable obstacles on the other side. While digital production can either be bundled spatially efficient or organized in small decentralized areas, there are challenges for integration into city-compatible logistics systems and intelligent transport and traffic concepts. New driving technologies and flexible transport containers offer the possibility of making freight transport more compatible with urban conditions. Nevertheless, elements of an urban freight transport are still predominantly designed for the distribution of goods. How the system has to be designed in order to offer flexible and acceptable conditions for production processes inside the city has so far received little attention. The role of logistics is becoming increasingly important in the globally networked economic process based on the division of labour. Based on the spatial distribution and separation of production and consumption, huge distribution centres are emerging outside cities, so-called "logistics landscapes" (see Waldheim \& Berger, 2008 and Snyder \& Wall, 1998), with enormous effects on traffic volume and energy consumption. The integration of this link into the urban fabric is a central challenge. Various European cities, such as Berlin, have adopted an area protection concept ("Berlin Integrated Commercial Transport Concept" (Kunst \& Billwitz, 2005)). Vienna has developed the "Productive City" concept (MA 18, 2017) for this purpose.

This study was part of the research project "Vertical Urban Factory" (Haselsteiner et al., 2019) that assessed architectural, legal and transportation parameters for vertical production in cities. For the project, we built on the concept of the vertical urban factory (Rappaport, 2016). The objective was to assess the possibility of reintegrating multi-storey production in European cities. To this end, we took Vienna as an example of a typical European city and developed five prototypes of "vertical urban factories" considering the existing urban structure, legal restrictions, global and local objectives, production needs and urban freight logistics. In this paper, we focus on the transportation aspects and present three of the five prototypes.

\section{METHODS}

Firstly, we analyzed the existing urban structure of Vienna (which is similar to those of other historic European cities) in the context of land use and transportation. This included the assessment of building density and height as well as the accessibility by walking, cycling, public transport (PT) and private motorized vehicles. Simultaneously, we visited existing production facilities with vertical concepts.
Secondly, we carried out a multi-criteria analysis by comparing the needs of factories, spatial and legal restrictions of cities and global to local objectives in terms of land use and transportation. As a third step, we developed prototypes of vertical urban factories reflecting the considered criteria (one prototype for each type of area). The prototypes are 3D models showing the size, rough floorplans and transportation concept of the schematic factories. In addition, we specified the relation of the building with its surroundings, such as the transport system and land use of adjoining buildings.

\section{RESULTS}

\subsection{Urban structure}

For the purpose of this study, the urban structure of Vienna can be divided into three major different types of areas for production facilities: integrated individual production facility, mixed commercial area and industrial-commercial area. These types correspond to the areas defined in the city's thematic concept "productive city" (MA 18, 2017). The integrated individual production facility is a single factory, embedded in a dense urban structure with mainly residential use. Existing factories of this type are usually historic ones that were built in an industrial area where residential buildings have approached with city expansion. Mixed commercial areas combine residential, commercial and industrial use. Such areas have generally been densified more recently and still show lower building density. Industrial-commercial areas can be found usually on the outskirts of the city. They have no residential buildings, mostly hall constructions and spacious traffic areas. Table 1 gives an overview of how the three types correspond to transportation parameters that are relevant for production.

Table 1. Three types of areas for production facilities and their transportation parameters

\begin{tabular}{|c|c|c|c|}
\hline $\begin{array}{c}\text { Transportation } \\
\text { parameters }\end{array}$ & $\begin{array}{l}\text { Integrated } \\
\text { individual } \\
\text { production } \\
\text { facility } \\
\end{array}$ & $\begin{array}{c}\text { Mixed } \\
\text { commercial area }\end{array}$ & $\begin{array}{l}\text { Industrial- } \\
\text { commercial } \\
\text { area }\end{array}$ \\
\hline Logistics area & $\begin{array}{c}\text { Densely built-up; } \\
\text { limited logistics } \\
\text { area }\end{array}$ & $\begin{array}{c}\text { Variable } \\
\text { availability of } \\
\text { logistics area }\end{array}$ & $\begin{array}{c}\text { Generally } \\
\text { high } \\
\text { availability of } \\
\text { logistics area }\end{array}$ \\
\hline Parking area & $\begin{array}{l}\text { Mixed use and } \\
\text { densely built-up; } \\
\text { limited parking } \\
\text { area }\end{array}$ & $\begin{array}{l}\text { Rather sufficient } \\
\text { parking area }\end{array}$ & $\begin{array}{c}\text { Sufficient } \\
\text { parking area }\end{array}$ \\
\hline $\begin{array}{l}\text { Accessibility } \\
\text { (public } \\
\text { transport, } \\
\text { walking and } \\
\text { cycling) }\end{array}$ & $\begin{array}{l}\text { High accessibility, } \\
\text { short distances }\end{array}$ & $\begin{array}{l}\text { Medium quality of } \\
\text { accessibility; } \\
\text { acceptable } \\
\text { access by public } \\
\text { transport }\end{array}$ & $\begin{array}{l}\text { Insufficient } \\
\text { accessibility }\end{array}$ \\
\hline $\begin{array}{l}\text { Accessibility } \\
\text { (motorised } \\
\text { vehicles) } \\
\end{array}$ & $\begin{array}{l}\text { Limited } \\
\text { accessibility }\end{array}$ & Good accessibility & $\begin{array}{l}\text { Very good } \\
\text { accessibility }\end{array}$ \\
\hline $\begin{array}{l}\text { Delivery } \\
\text { restrictions }\end{array}$ & Strict restrictions & $\begin{array}{l}\text { Restrictions are } \\
\text { important }\end{array}$ & $\begin{array}{c}\text { Little } \\
\text { restrictions }\end{array}$ \\
\hline
\end{tabular}




\subsection{Multi Criteria Analysis}

Objectives that are relevant for urban production reach from global (such as the UN Sustainable Development Goals (UN General Assembly, 2015) or the Paris Agreement (UNFCCC, 2015)) to national (e.g. climate and energy strategy of Austrian government (BMVIT, 2018)) to local (e.g. urban development plan of Vienna (MA 18, 2014)). The current overall goal is decarbonisation. This demands restrictions for private motorized transport, better conditions for alternative modes of transportation including more density and mixed use to support short trips. Fortunately, these measures also promote sustainability and liveability in cities and align with the local city objectives. The concept of the vertical urban factory promotes the goals in shortening trips for freight, employees and customers, adding to the density of the city and providing mixed use.

Nevertheless, there are also challenges for incorporating vertical factories in cities. Neighbours can be disturbed by delivery traffic and production itself. Population growth puts pressure on administrations to construct residential buildings instead of preserving old production facilities and constructing new ones. Public space is limited in denser areas. This can result in conflicts of interest for that space. Figure 1 shows the relations between transportation parameters of cities and production parameters of factories. Interdependencies between transportation parameters are indicated with two-sided arrows.

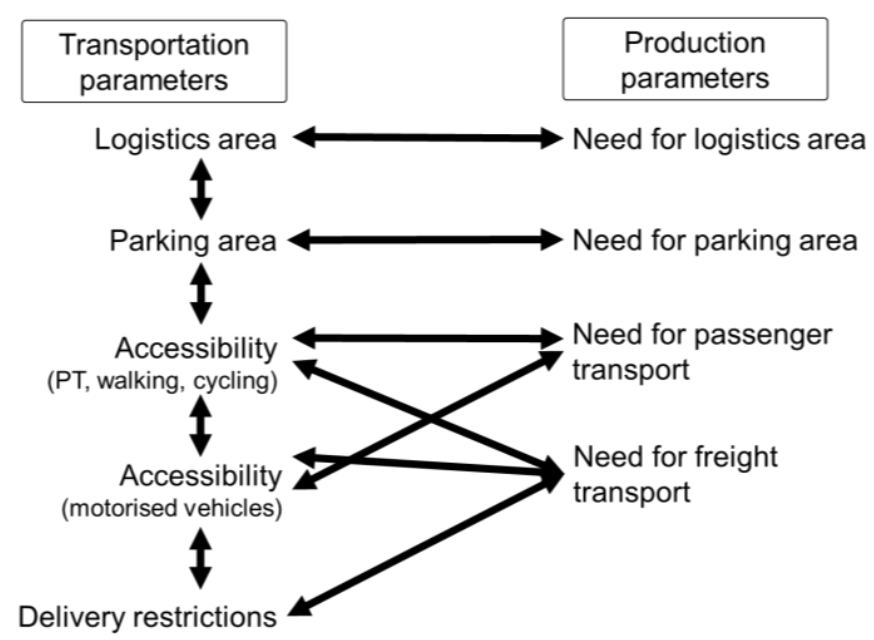

Figure 1. Relations between transportation parameters of cities and production parameters of factories

We identified that the production parameters that correspond to the transportation parameters are depending more on the scale of production and less on the type of industry. The scale of production determines the frequency of deliveries and size of transport vehicles. Therefore, the prototypes are not assigned to specific industry types but to production scales.
Unsurprisingly, in the current state, small scale productions best fit the area type integrated individual production facility while big scale productions are best suited for industrial-commercial areas. This is mainly due to the fact that in industrial-commercial areas, there are no delivery restrictions, better accessibility for motorized vehicles and more available area for parking and logistics.

On the other hand, considering the global and local objectives, integrated individual production facilities fit the objectives best. They offer very good accessibility for non-motorized modes of transportation and mixed use. Nevertheless, the highest potential for vertical urban factories can be found in mixed use areas. There, accessibility for motorized as well as non-motorized modes of transportation is acceptable and there is still space available for densification. If we consider the needs for production facilities and sustainable transportation in future planning of densification and land use, good conditions for vertical urban factories can be achieved. Industrial-commercial areas can also be a use case for vertical factories in the process of densification. However, for now, they have rather poor accessibility and monofunctional land use and are therefore less attractive for applying the concept.

\subsection{Prototypes}

We present three different prototypes of vertical urban factories, one for each type of area. They reflect common challenges according to the type of area as well as suitable solutions. Certain principles of transport planning are part of all the prototypes. These include priority access by public transport, walking and cycling and bicycle parking close to the entrance. Yellow shaded areas inside the buildings are "access cores" featuring logistics areas, elevators and staircases.

Underground parking in the basement floors of the buildings was included to account for existing laws requiring car parking (e.g. WGarG 2008 in Vienna). At this point, we would like to note that on-site parking is not in line with global and city objectives to reduce private car use. It creates an advantage for the use of private cars compared to public transport, since walking distance to the parking place is shorter than to the public transport stop. The effect of parking distance on mode choice was shown e.g. by Parikesit (1996), Knoflacher (2006) and Emberger \& Pfaffenbichler (2017).

\section{Integrated individual production facility}

This prototype was fit into a block of the typical closed block construction style of the Gründerzeit (second half of the $19^{\text {th }}$ century). The challenge for this prototype is primarily the conflict of space in the densely built environment. Solutions for this are for example sharing concepts that are part of the typology. The courtyard serves as a shared logistics and meeting area. Large delivery trucks can access the courtyard in a one-way manner, though use of smaller vehicles such as cargo 
bikes is encouraged by designated cargo bike parking. Outside the building, in public space, is a "multifunctional lane" which can serve as delivery zone, parking space or seating area depending on the time of day and year. Figure 2 to Figure 4 show the 3D visualization, material and people flows and transportation concept of the prototype.

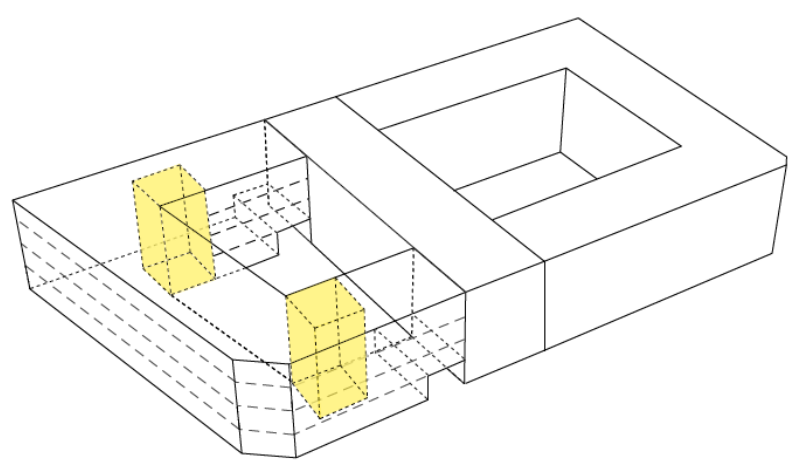

Figure 2. 3D visualization prototype integrated individual production facility

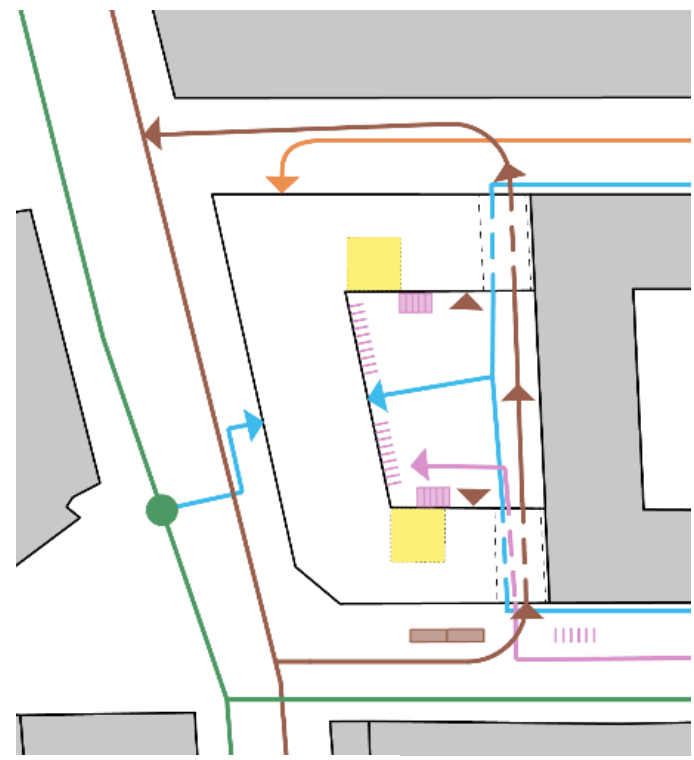

LEGEND:

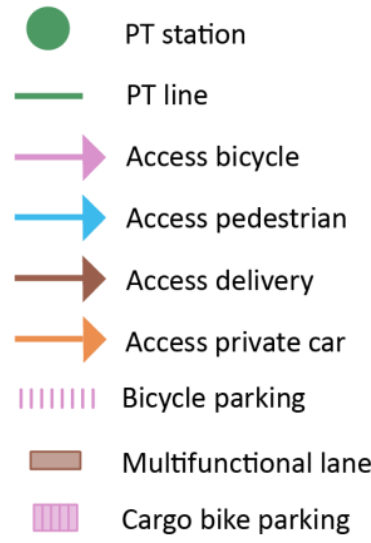

Figure 3. Transportation concept integrated individual production facility

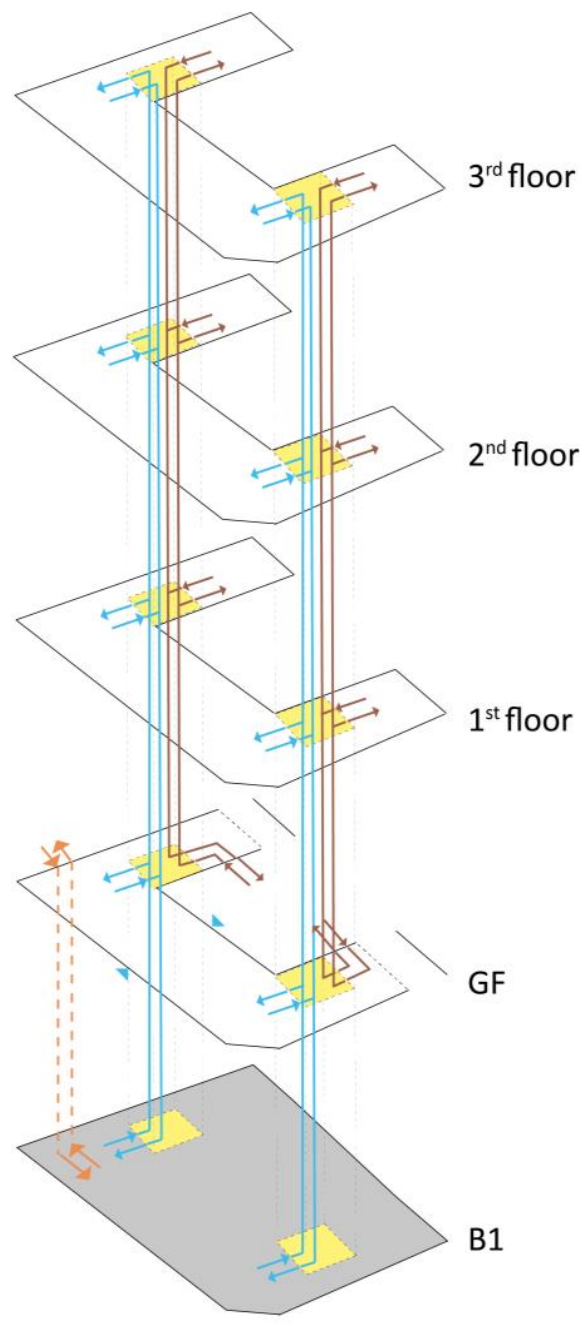

LEGEND:

$\longrightarrow$ People flow

$\longrightarrow$ Material flow

$\longrightarrow$ Access car

Figure 4. People and material flow integrated individual production facility; GF...Ground floor, B...Basement

\section{Mixed commercial area}

For the mixed commercial area, we developed a concept where the building serves as a buffer between a high-ranked transportation axis (e.g. a busy road or a railway line) and a residential area. This shields residents from noise and exhausts while providing access for delivery vehicles. The access for people to the building is located on the backside at a lane closed for motorized vehicles. At the side facing the transportation axis, delivery trucks can access and exit the delivery area. This design creates a protected area at the backside that serves simultaneously as a pleasant pathway and meeting area for employees and residents, making a positive contribution to the neighbourhood. The prototype for mixed commercial areas is shown in Figure 5 to Figure 7. 


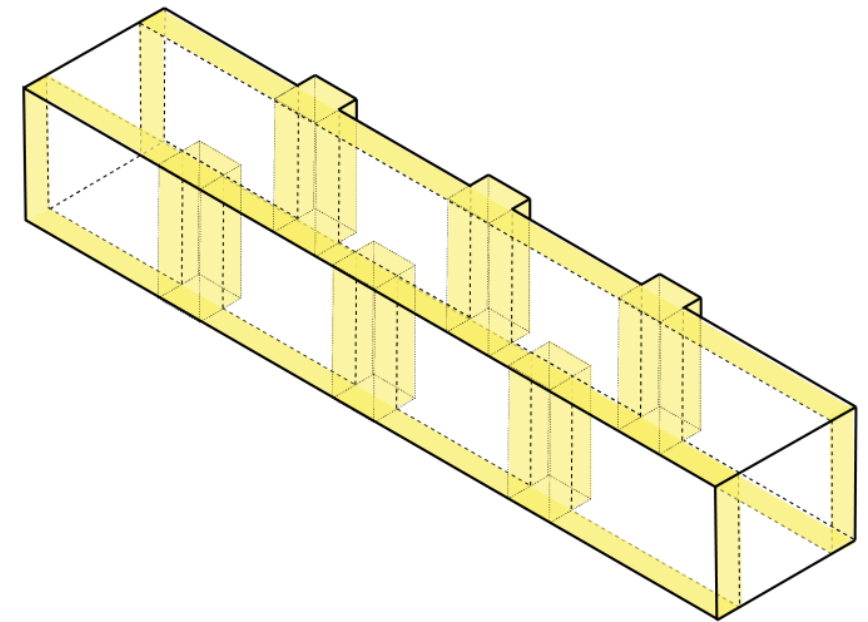

Figure 5. 3D visualization prototype mixed commercial area

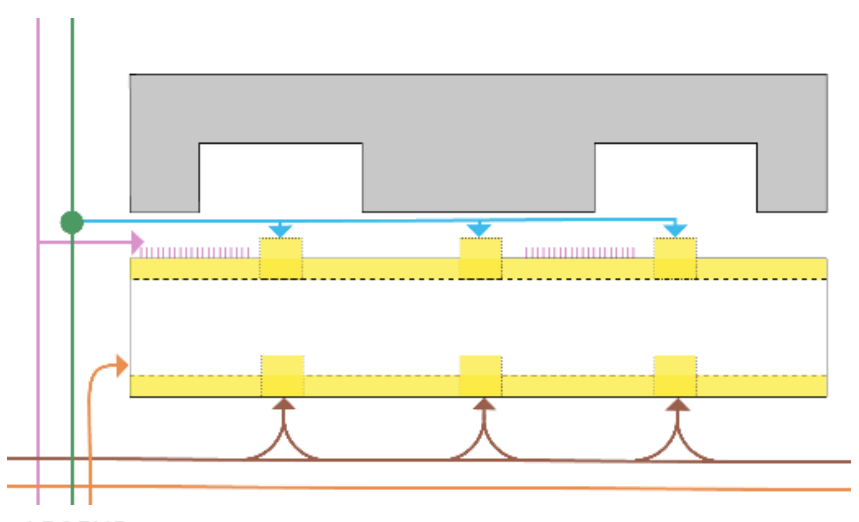

LEGEND:

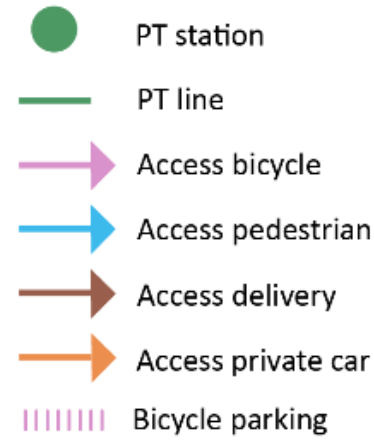

Figure 6. Transportation concept mixed commercial area

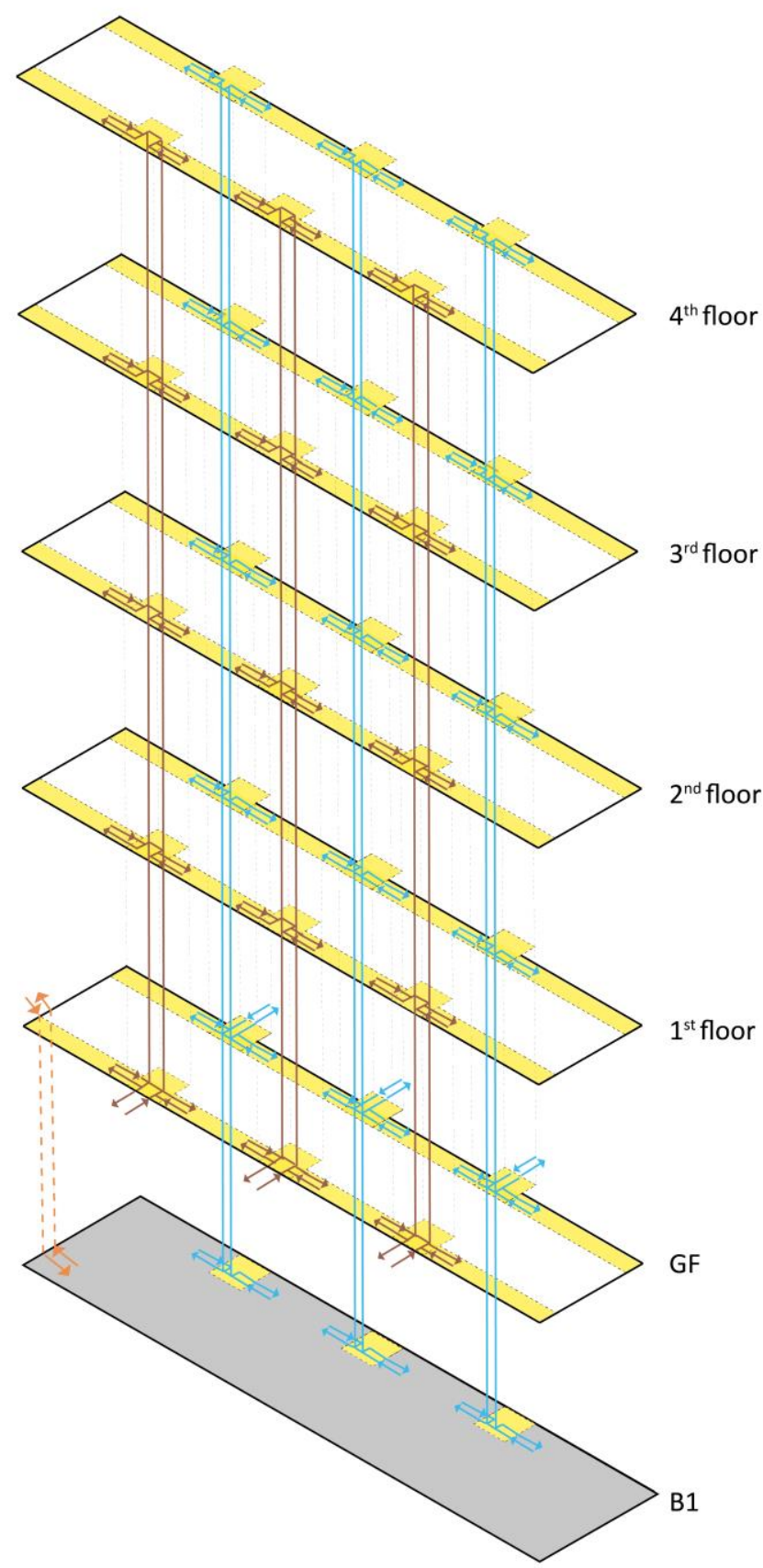

LEGEND:

$\longrightarrow$ People flow

$\longrightarrow$ Material flow

$\longrightarrow$ Access car

Figure 7. People and material flow mixed commercial area; GF...Ground floor, B...Basement

\section{Industrial-commercial area}

The prototype for industrial-commercial areas is based on a common hall construction, expanded by two multistory buildings. It shows how an industrial area dominated by single-story buildings could be densified. Access for delivery and people is separated. At the street-side, people can access the building from a PT stop, by walking or cycling. The large area in front of the 
hall features customer parking, a logistics area and bicycle parking close to the entrance but can also be used for events and as a meeting area. Access for delivery trucks is located at the other side of the building. Figure 8 to Figure 10 show the Industrialcommercial area prototype.

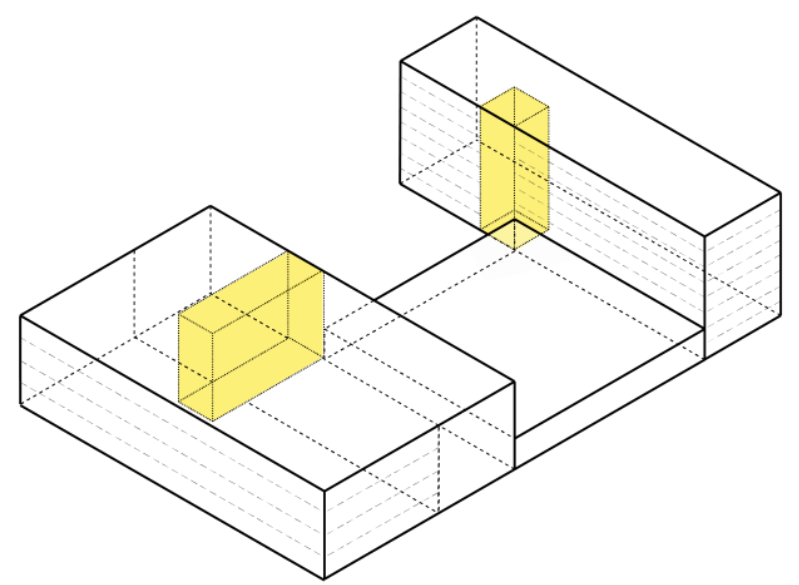

Figure 8. 3D visualization prototype industrial-commercial area

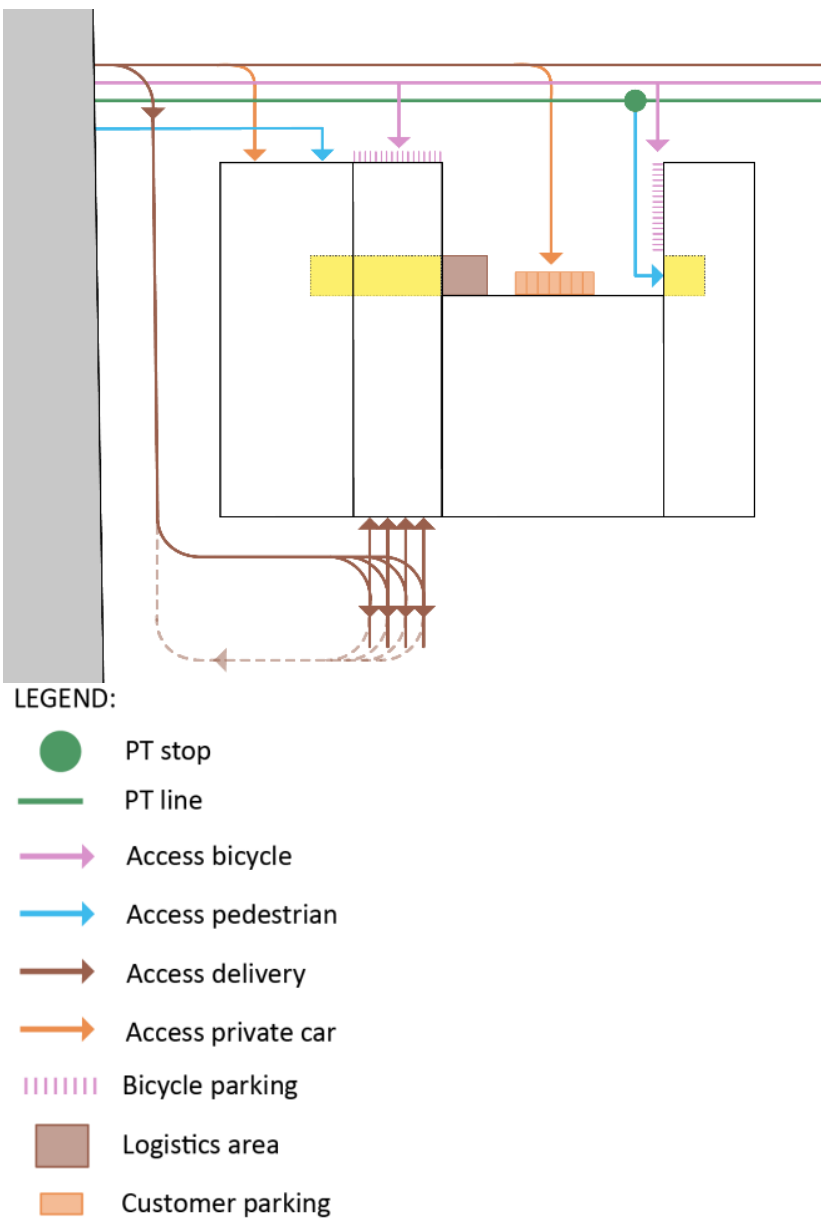

Figure 9. Transportation concept industrial-commercial area

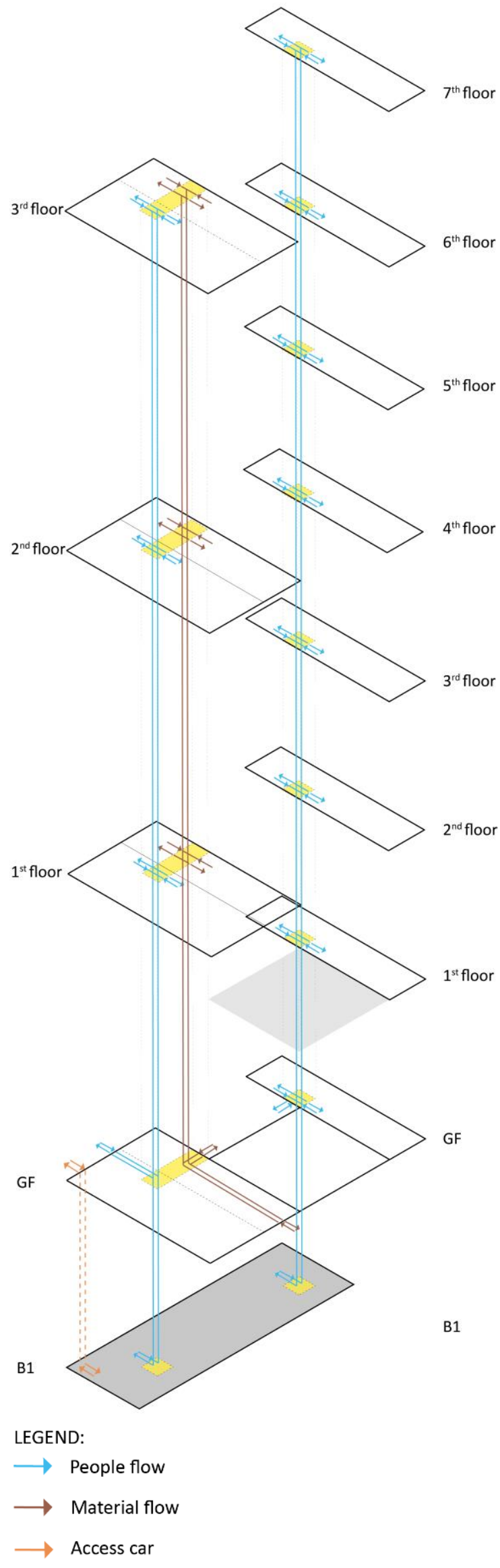

Figure 10. People and material flow industrial-commercial area; GF...Ground floor, B...Basement 


\section{DISCUSSION}

Our prototypes show that it is possible to reintegrate vertical urban factories in typical European urban structures, in terms of transport systems and available space. However, there are also legal issues that have to be considered. One of the reasons companies choose to relocate production sites outside of cities is the legal situation that favors residents' rights. While it is necessary to shield residents from dangerous emissions, even factories that have been built long before neighboring housing units can be forced to shut down due to complaints. This aspect is not part of this study but should be addressed by cities if they choose to encourage urban production.

Another limitation of our study is the consideration of single handicraft facilities. While they are an important part of cities and should be promoted, such facilities are not subject of this study. Instead, we focused on larger factories that comprise at least a whole building.

Regarding such larger factories, new and rediscovered technologies can be of aid to overcome current challenges. Production techniques such as 3D printing, computer numerical control milling and laser cutting make it possible to produce decentralized on a low scale down to lot size one.

This enables the use of smaller factories with lower transport volumes per site. Smaller vehicles and alternative engines help in making the logistics of urban factories more compatible with traffic calming measures and objectives of reduced $\mathrm{CO}_{2}$ emissions. Cargo bikes could play a major role in future urban logistics. Demand for and production of cargo bikes are on the rise again (Ghebrezgiabiher \& Poscher-Mika, 2018).

A German study calculated that already $23 \%$ of all commercial trips can be substituted with cargo bikes (Gruber et al., 2016). Vehicle manufacturers are working on traditional delivery vehicles with electric engines as well as new types of vehicles that are smaller and more efficient in urban environments. Sharing concepts further facilitate the incorporation of production facilities in densely built areas.

Concepts such as multifunctional lanes and shared loading yards are already in use in different cities (e.g. (MA 18, 2017), (Gronalt \& Posset, 2015)). This multiuse of private and public space can help relieve tensions due to limited space and conflicting interests. Therefore, our prototypes include such concepts, e.g. in the form of parking places for cargo bikes or multi-use areas. Many solutions already exist; they only have to be incorporated by city administrations, planners, developers and companies.

\section{CONCLUSION}

We conclude that multi-storey construction represents indeed a realisable alternative for limited space resources and urban production. Depending on the type of area, type of development or infrastructural conditions, very different space-saving concepts are possible, which can be adapted to company-specific requirements.

The integrated individual production facility best fulfils the transport policy objectives with regard to traffic influencing factors. Although there are restrictions for motorized individual transport (e.g. number of parking spaces) and higher costs due to logistics, these production locations are easily accessible with the public transport system. However, the greatest potentials for vertical factories are located in mixed commercial areas, which have been developed as a result of urban densification and in the sense of busy urban spaces with mixed use.

Vertical urban factories promote sustainability goals on several levels. They can shorten trips for freight, employees and customers and help strengthening local economic cycles. They add to the density of the city and provide mixed-use areas. We recommend to cities to promote vertical production. For this, it is necessary to include production land-use in city codes and reserve space for logistics. Additionally, cities should provide a legal framework that enables factories to stay in cities whilst protecting residents from harmful emissions.

Future research on vertical urban factories could analyze quantitatively the impact of such factories on economic and sustainability indicators or analyze how our prototypes can be transferred to other cities. Real world applications should be encouraged and existing vertical factories should be supported by cities. They can further serve as case studies to deepen the knowledge about vertical factories and their integration to existing urban structures.

\section{Acknowledgements}

This paper was written in the course of the FFG funded project „VERTICALurbanFACTORY - Kriterien, Potenziale und innovative Konzepte der vertikalen Verdichtung von Produktion und Stadt"; Call "Stadt der Zukunft -4. Ausschreibung 2016", project no. 861718. 


\section{References}

[1] BMVIT. (2018). \#mission2030 - Die österreichische Klima- und Energiestrategie. In Bmvit (Ed.).

[2] Emberger, G., \& Pfaffenbichler, P. (2017). Equidistance: Evidence of the Influence of Parking Organization on Mode Choice. In Engineering Tools and Solutions for Sustainable Transportation Planning (pp. 22).

[3] Ghebrezgiabiher, J., \& Poscher-Mika, E. (2018). Cargobike Boom - Wie Transporträder unsere Mobilität revolutionieren: MAXIME Verlag.

[4] Gronalt, M., \& Posset, M. (2015). Best Practice Toolbox Katalog von nationalen und internationalen Referenzprojekten für Güterverkehr und Logistik in Städten. Wien: Klima- und Energiefonds.

[5] Gruber, J., Rudolph, C., Lenz, B., Liedtke, G., Spath, C., \& Wrighton, S. (2016). Untersuchung des Einsatzes von Fahrrädern im Wirtschaftsverkehr (WIV-RAD).

[6] Haselsteiner, E., Madner, V., Frey, H., Grob, L.-M., Laa, B., \& Schwaigerlehner, K. (2019). VERTICALurbanFACTORY Innovative Konzepte der vertikalen Verdichtung von Produktion und Stadt. URL (after end of project): https://nachhaltigwirtschaften.at/de/sdz/projekte/vertical-urbanfactory.php

[7] Juraschek, M., Bucherer, M., Schnabel, F., Hoffschröer, H., Vossen, B., Kreuz, F., Herrmann, C. (2018). Urban Factories and Their Potential Contribution to the Sustainable Development of Cities. Procedia CIRP, 69, 72-77. doi:10.1016/j.procir.2017.11.067

[8] Knoflacher, H. (1995). Economy of Scale - Die Transportkosten und das Ökosystem. GAIA - Ecological Perspectives for Science and Society, Vol. 4, 2/1995, 100-108(9). doi:10.14512/gaia.4.2.8

[9] Knoflacher, H. (2006). A new way to organize parking: the key to a successful sustainable transport system for the future. Environment \& Urbanization, 18(2), 387-400. doi:10.1177/0956247806069621

[10]Kunst, F., \& Billwitz, G. (2005). Integriertes Wirtschaftsverkehrskonzept Berlin.

[11]MA 18. (2014). STEP 2025: Stadtentwicklungsplan Wien ; Mut zur Stadt (Ma Ed. Nachdruck ed.). Wien: Magistratsabteilung 18 - Stadtentwicklung und Stadtplanung.

[12]MA 18. (2017). STEP 2025 - Fachkonzept Produktive Stadt. Wien.

[13]Parikesit, D. (1996). Zusammenhang zwischen Verkehrsinfrastrukturangebot und Ortswahl und seine Auswirkung auf den Energieverbrauch im Verkehrssystem. Dissertation, Technische Universität, Wien.

[14]Rappaport, N. (2016). Vertical Urban Factory. New York: Actar.

[15]Snyder, S. N., \& Wall, A. (1998). Emerging landscapes of movement and logistics. Architectural Design Profile, 134, 1621.
[16]UN General Assembly. (2015). Transforming our world: the 2030 Agenda for Sustainable Development. A/RES/70/1

[17]UNFCCC. (2015). Paris Agreement.

[18]Waldheim, C., \& Berger, A. (2008). Logistics Landscape. Landscape Journal, 27(2), 219-246. doi:10.3368/lj.27.2.219 